\title{
Efficiency of Practical-Based Education in Preparatory Schools, the Case of Horo Guduru Wollega Zone, Ethiopia
}

\author{
Adugna Mosissa \\ Department of Food Science and Nutrition, Wollega University, Shambu, Ethiopia \\ Email address: \\ a.mosissa@yahoo.com \\ To cite this article: \\ Adugna Mosissa. Efficiency of Practical-Based Education in Preparatory Schools, the Case of Horo Guduru Wollega Zone, Ethiopia. \\ Advances in Sciences and Humanities. Vol. 3, No. 3, 2017, pp. 14-22. doi: 10.11648/j.ash.20170303.11
}

Received: April 7, 2017; Accepted: May 5, 2017; Published: June 5, 2017

\begin{abstract}
This research was carried out in four preparatory schools (Shambu, Hareto, Fincha and Amuru) out of 10 senior schools in Horo Guduru Wollega Zone. The study was designed to investigate the existing practical-based learning practices and systems of the preparatory schools as well as to provide baseline information awaking concerned bodies for future successful practically supported education. Among the school societies; directors of the schools, teachers and students were incorporated in the sample. Random sampling method was used to select students and teachers for questionnaire and interview, and a total of 200 students and 40 teachers were taken. This investigation showed that, there were opportunities to promote practical-based educational activities. But there was no good system of implementing a practical-based education in the schools under study. The reasons were: the absence (limitation) of materials, arranged programs for practical activities, assigned human resource for handling the practical activities, interest of the teachers and attention given to practical-based education by the management bodies. According to the finding, the teachers working in the target schools have awareness about the importance of practical-based learning that promote acquisition of long lasting knowledge and skill at preparatory school level. But, in practice the teachers didn't make practical activities the part of their teaching methods as well as assessment methods. There were almost no functional laboratories and limited trial to promote practical-based education in the schools. Even the operating laboratories using available materials depend on the good will of the subject teacher to shoulder the load in addition to the regular class loads. Most of the students in the schools reflected that they were interested in practical-based education, but the door was not open for them to undertake practical learning in their context. For the failure they complained the management system of the schools and interest of the teachers. The educational offices at all levels, school officials, teachers and other concerned bodies need to cooperate to promote practical-based education at preparatory school level. This may need planning for practical activities, training teachers, hiring laboratory technicians (attendants), fulfilling facilities and programming practical activities.
\end{abstract}

Keywords: Practical-Based Learning, Active Learning, Laboratory Activity, Knowledge

\section{Introduction}

\subsection{Background}

In Ethiopia, Primary education lasts eight years and is divided into grades 1-4 (primary first cycle) and grades 5-8 (primary second cycle). Secondary education is also divided into two cycles, each with its own intended goals. Grades 910 (secondary first cycle) provide general secondary education and, upon completion, students are streamed either into grades 11-12 (secondary second cycle) as preparation for university, or into technical and vocational education and training (TVET), based on their performance in the first cycle secondary education completion certificate examination. General education comprises grades 1 to 12 according to the country's policy.

Horo Guduru Wollega zone encompasses 10 woredas. This year, there are 12 preparatory schools $\left(11-12^{\text {th }}\right.$ grade), 35 secondary schools $\left(9-10^{\text {th }}\right.$ grade) and 304 primary schools (1$8^{\text {th }}$ grade) in the zone. Most of these schools are not fully equipped with necessary facilities. For example; laboratories are rarely operational and libraries are insufficient. The 
problem of educational quality touches every stakeholder and availability of important facilities determines educational quality.

The current educational policy of the country is designed in a way that schools should exercise active learning methods. They have to learn to develop their knowledge and skill in order to cope up with the fast growing economic and industrial activities. It is achieved by following practicalbased learning system. This type of education helps the learners to acquire skill, not only knowledge. However, its translation in to action is not easy task. The major part of the education is still theoretical.

Students may develop their knowledge and skill in their subject areas through their education using different systems. For example; laboratories, field visit, drawings, environment observation, models, demonstrations, problems etc are some of the methods that can be used.

\subsection{Developing Knowledge and Skill Through Learning}

Currently, practical-based education is widely accepted as a quality form of education. Learning requires the individual to be active and to be engaged in the construction of one's own mental models [22]. According to constructivist educators, learning is an active acquisition of ideas and knowledge construction, rather than a passive process [5], [17].

Problem-based learning is an instructional approach that offers the potential to help students develop flexible understanding and lifelong learning skills [12]. This way of learning has been recommended in science education since it improves students' achievement [9].

These days, there is a growing emphasis that students should develop professional skills in the course of their education. These may include team skills, problem solving skills, decision making skills, communication skills, information literacy skills, time management skills and many others [26]. To develop such skills, learners have to engage in tasks that are likely to help them reflect on their own success in completing tasks, and that of their peers.

The 2005 EFA [Education Funding Agency] Global Monitoring Report said that "Formal schooling is one of several important contributors to the skills of an individual and to human capital. Schools nonetheless have a special place, not only because education and 'skill creation' are among their prime explicit objectives, but also because they are the factor most directly affected by public policies."

Therefore, the main objective of formal school is not only to teach theoretical imagination of things or objects, but also to facilitate skill acquisition. Therefore schools should play their role in supporting skill development of learners at all levels of education. Public policies, school organization, educational environment, teacher behavior, and learners' commitment are some of the factors that affect learning outcomes [7].

Quality education includes outcomes that encompass knowledge, skills and attitudes, and are linked to national goals for education and positive participation in society. Life skills curriculum focuses on attitudes, values and behavioral change, rather than seeking to provide young people with a body of knowledge about a set of topics [4].

Many higher education sectors today deliver education that has both a theoretical and practical basis, from medicine to engineering, in order for it to be relevant to the world of work. A report produced by USAID [United States Agency for International Development] (2011) showed that, in Ethiopian education there is high-quality implementation, the use of cooperative agreements, adequate resources fairly distributed. According to this report, much stronger attention should be given to follow-on and mentoring, and more careful monitoring of the quality of services provided. This should go far in building on the efforts to date and to the delivery of the quality education so necessary for Ethiopia's present, and future [25]. Therefore, for today's Ethiopian economy a well skilled educated people are very important to travel with the greatly increasing world competition.

\subsection{Practical-Based Education}

Practical work is an essential part of science education. In science lessons, it need to extend students' knowledge of the natural world and develop their understanding of the ideas, theories and models that scientists have found useful in explaining and predicting its behavior.

Stages in the development and evaluation of a teaching and learning activity can be viewed in four steps: A developers' objectives (what the students are intended to learn), Task specification (what the students are intended to do), Classroom events (what the students actually do) and Learning outcomes (What the students actually learn) [21].

Practical learning is a matter of 'acquiring skills', while academic learning involves imagination, cogitation and a much more sophisticated attitude towards knowledge and understanding. Skills are technical, relatively clear-cut, trainable, and, once acquired, available whenever they are appropriate to use. Once you have been trained in a skill, you go out and practice it (with occasional short refreshers and updating), whilst an educated mind thirsts for ever-deepening understanding [11].

The relationship between educational attainment and skills acquisition appears obvious and reasonable. It can be viewed as the primary vehicle by which literacy and numeracy skills learned. A formal education enhances skill levels of the learners. Those with greater levels of educational attainment naturally have higher skill levels [10].

Many scholars have long known of the complicated connections which exist between mind and body and the important role of physical activity in absorbing abstract concepts and learning practical skills. Practical work always has a key role in science teaching. The challenge is to find ways to make it more effective as a teaching and learning strategy than it often is at present.

\subsection{Problem Statement}

People need a broad range of knowledge and skills in order to contribute to a modern economy. Researchers and authors recommended practical-based knowledge and skill 
development through the course of their formal education. Moreover, the current global educational policies encourage active learning, in which learners get the opportunity to manifest their potential and develop their skills. However, the education system is observed to be still more of theoretical. The schools should be special places for knowledge and skill development of the students through their education. But, awareness of the schools stakeholders for practical learning is low. Therefore, this survey research is designed to investigate the level of practical-based knowledge and skill developing practices of the preparatory schools and to provide baseline information awaking concerned bodies for future planning of practically supported education.

\subsection{Objectives}

The main objectives of this research were to:

a) Assess the status of practical-based learning practices of the preparatory schools in Horo Guduru Wollega Zone.

b) Identify methods of practical-based learning currently used in the preparatory schools

c) Assess awareness of the schools' teachers and students about practical-based education

\section{Methods}

This study was carried out in selected four preparatory schools (Shambu, Fincha, Amuru and Hareto) of Horo Guduru Wollega Zone. Shambu preparatory school is found in Shambu town, the capital of the Zone. And Fincha, Amuru and Hareto preparatory schools are found in Abay Chomen, Amuru and Jimma Geneti woredas respectively.

Out of 10 senior preparatory schools in the zone, four schools were selected for the study. Among the school societies, directors of the schools, teachers and students were incorporated in the sample. Random sampling method was used to select students for questionnaire and interview. A total of 200 students (50 from each school) were taken for the study (Table 1).

Table 1. Number and gender of students included in the sample.

\begin{tabular}{lllll}
\hline \multirow{2}{*}{ No. } & \multirow{2}{*}{ School name } & \multicolumn{3}{l}{ Number of Sample } \\
\cline { 3 - 5 } & & Male & Female & Total \\
\hline 1 & Shambu & 26 & 24 & 50 \\
2 & Hareto & 26 & 24 & 50 \\
3 & Fincha & 26 & 24 & 50 \\
4 & Amuru & 28 & 22 & 50 \\
Total & & 106 & 94 & 200 \\
\hline
\end{tabular}

Similarly, 40 available teachers (10 from each school) were taken as a sample (Table 2).

Table 2. Number and gender of teachers included in the sample.

\begin{tabular}{lllll}
\hline \multirow{2}{*}{ No. } & \multirow{2}{*}{ School name } & \multicolumn{3}{l}{ Number of Sample } \\
\cline { 3 - 5 } & & Male & Female & Total \\
\hline 1 & Shambu & 10 & 0 & 10 \\
2 & Hareto & 10 & 0 & 10 \\
3 & Fincha & 9 & 1 & 10 \\
4 & Amuru & 10 & 0 & 10 \\
Total & & 39 & 1 & 40 \\
\hline
\end{tabular}

The study was strongly dependent on primary data. The data was collected by implementing different data collection tools. Observation technique was used for collecting evident information such as laboratory facilities, class room facilities, and demonstration rooms. Also a well-organized and printed (delivery and collection) questionnaire was distributed to the sample teachers and students. In addition, semi-structured interviews were implemented to collect necessary and complementary data.

The data was presented in a form of tables and graphs. The result was analyzed using inductive method for qualitative data and descriptive statistics for quantitative data including frequencies, means, standard deviations and percentages. Statistical Package for Social Studies (SPSS) and MS-Excel software were used for inferential statistical evaluation.

\section{Result}

\subsection{Background of the Schools}

The number of male and female students is almost proportional in the schools; but only $5.7 \%$ of the teachers were females. The data of teachers and students of each of the schools were presented as follows for 2015/16 academic year.

Table 3. Number of students and teachers in the target preparatory schools (Grades 11 \& 12).

\begin{tabular}{llllllll}
\hline \multirow{2}{*}{ No. } & School & \multicolumn{3}{c}{ Number of Students } & \multicolumn{3}{c}{ Number of Teachers } \\
\cline { 3 - 8 } & name & Male & Female & Total & Male & Female & Total \\
\hline 1 & Shambu & 568 & 543 & 1111 & 42 & 3 & 45 \\
2 & Hareto & 691 & 672 & 1363 & 29 & 3 & 32 \\
3 & Fincha & 710 & 760 & 1470 & 39 & 3 & 42 \\
4 & Amuru & 578 & 588 & 1166 & 40 & 0 & 40 \\
Total & & 2547 & 2563 & 5110 & 150 & 9 & 159 \\
\hline
\end{tabular}

The average student-teacher ratio for the schools under study was about 32 . That means one teacher for 32 students.

Table 4. Average student-teacher ratio of the schools (Number of Students/ Number of teachers).

\begin{tabular}{lllll}
\hline No. & $\begin{array}{l}\text { School } \\
\text { name }\end{array}$ & $\begin{array}{l}\text { Number of } \\
\text { Students }\end{array}$ & $\begin{array}{l}\text { Number of } \\
\text { teachers }\end{array}$ & $\begin{array}{l}\text { Student- } \\
\text { teacher ratio }\end{array}$ \\
\hline 1 & Shambu & 1111 & 45 & 25 \\
2 & Hareto & 1363 & 32 & 43 \\
3 & Fincha & 1470 & 42 & 35 \\
4 & Amuru & 1166 & 40 & 29 \\
Average & & 1278 & 40 & 32 \\
\hline
\end{tabular}

Class size (number of students per class) is another factor to be considered here that may affect the implementation of practical education. Average class size for the schools under investigation is put in the following table (Table 5) based on the data obtained during the study. 
Table 5. Average class size of the schools (Number of Students/ Number of classes).

\begin{tabular}{lllll}
\hline No. & $\begin{array}{l}\text { School } \\
\text { name }\end{array}$ & $\begin{array}{l}\text { Number of } \\
\text { Students }\end{array}$ & $\begin{array}{l}\text { Number of } \\
\text { classes }\end{array}$ & $\begin{array}{l}\text { Average class } \\
\text { size }\end{array}$ \\
\hline 1 & Shambu & 1111 & 21 & 53 \\
2 & Hareto & 1363 & 18 & 75 \\
3 & Fincha & 1470 & 24 & 62 \\
4 & Amuru & 1166 & 22 & 53 \\
Average & 1277 & 21 & 61 \\
\hline
\end{tabular}

\subsection{Background of the Students}

The investigation revealed that over $69.5 \%$ of the students were from rural areas and $63.1 \%$ of them were from farmer families. The term rural in this context refers to students living outside of the towns. The finding also showed that about $74.6 \%$ of the respondents developed good reading habits and even made reading their hobbies. Majority of the students under study were interested in reading and doing practical works related to their educational subjects.

\subsection{Student-Teacher Relation}

According to this finding, over $79 \%$ of the students responded that they have strong relationship with their teachers. And about $91 \%$ of them respect their teachers. But only $22.8 \%$ of the teachers approach their students friendly. However, about $16.3 \%$ of the teachers approach their students aggressively and unfavorably.

Based on the response of the teachers, $95.2 \%$ of the teachers have strong relationship with their students. And over $97.7 \%$ of the teachers responded that their students respect them. However, only $69.5 \%$ teacher respondents have free and friendly relationship with their students. The respect students have for their teachers and low free relationship between students and their teachers implies that the variation could be due to the teachers' behavior.

\subsection{Laboratory Facilities}

This investigation showed that there were opportunities to promote practical activities. But there was no good system of practicing a practical-based education in the schools under study. Materials were limited; no arranged programs for practical activities, no assigned human resource for handling the duties and attention not given to practical-based education by the management bodies.

Better activity was observed in Shambu preparatory school even though it is not sufficient. There were models, pictures and other observable materials to be observed by learners in the laboratories. Also ICT center of the school was open but not proportional to the number of students. Other than computer laboratory, the others (biology, chemistry, physics, etc) were not this much active. Only occasional observations were arranged for students. The teachers argued that materials are not sufficient and no professional technical assistant to run laboratory activities effectively.

In Hareto preparatory school, there were store of chemicals as well as materials that can be used for biology and chemistry practical works. However, the laboratory was not operational during this study. The reason was attributed to different limitations. Among these the major once were lack of professional technician, limitations in teachers competence, lack of interest on the teachers side.

According to the gathered information, there were almost no functional laboratories and limited trial to promote practical-based education in the other two schools (Fincha and Amuru). Facilities were not available and a trend of practical learning was not being exercised so far as this survey revealed.

Generally, operating laboratories even using the available materials depend on the good will of the subject teacher to shoulder the load in addition to the class loads.

\subsection{Status of Practical-Based Learning}

According to this finding, practical-based education is not efficient in almost all of the schools under study. Only computer laboratories and sport fields were occasionally active. In the preparatory schools considered in this study, little science laboratories were operational and field observations were not practiced. Teachers complain the lack of technical assistant and material facilities as well as the credit load they shoulder. But, the respective officials attribute the failure to the teachers' lack of interest. The study shows that both the school management, educational offices at all levels and the teachers paid little attention to practicalbased education to take place.

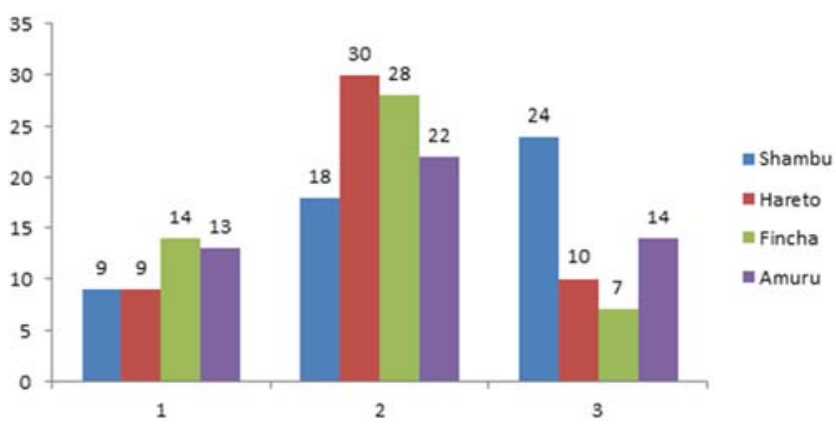

Figure 1. Frequency of using laboratories ( $1=$ Frequently, $2=$ Not at all, $3=$ Sometimes).

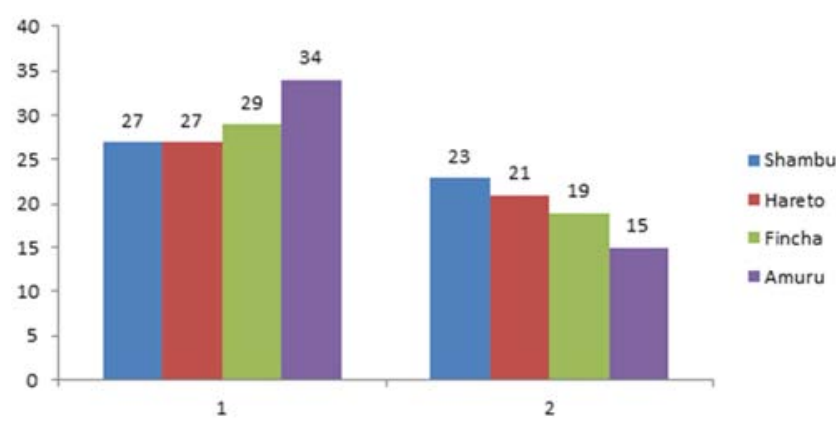

Figure 2. Number of students ever given experimental assignment or not given any experimental assignment ( $1=$ given, $2=$ not given $)$.

As it is shown in Figure 1, about 50\% of the respondents were not using laboratories at all. Relatively, Shambu preparatory school was better in using laboratories.

Actually, the concept of practical learning is not limited to 
laboratories. Activities such as field observations, drawings, project works, etc can be considered as practical learning methods. The finding showed that, about $40 \%$ of the students responded they were not ever given practical assignments (Figure 2).

According to the assessment made, most of the students in the schools were interested in practical-based education. But, the door was not open for the students to undertake practical learning in their context. They complained the management system of the schools and interest of the teachers.

\subsection{Teachers' Attitude Towards Practical Teaching}

This study tried to assess attitude of the schools' teachers towards practical teaching. The data collected from the target schools is presented in Table 6. Almost all the teachers included in the study responded that they believe that practical-based learning is important. This shows that they have awareness about practical learning at principle level but they didn't implemented in the real teaching-learning environment.

Table 6. Assessment of teachers' attitude towards practical or laboratory based learning.

\begin{tabular}{|c|c|c|c|c|c|c|c|}
\hline \multirow{2}{*}{ No. } & \multirow{2}{*}{ Subject } & \multicolumn{4}{|l|}{ School } & \multirow{2}{*}{ Total } & \multirow{2}{*}{ Percentage } \\
\hline & & Shambu & Hareto & Fincha & Amuru & & \\
\hline 1 & Teachers believing that practical-based learning is important & 10 & 10 & 10 & 10 & 40 & 100 \\
\hline 2 & $\begin{array}{l}\text { Teachers who believe that skill development is important at } \\
\text { preparatory school level }\end{array}$ & 9 & 9 & 12 & 10 & 40 & 100 \\
\hline 3 & Teachers using a picture when they teach & 6 & 7 & 7 & 9 & 29 & 72.5 \\
\hline 4 & Teachers using laboratories & - & - & 1 & 1 & 2 & 5.0 \\
\hline 5 & Teachers giving experimental assignments to their students & 1 & 1 & 2 & 3 & 7 & 17.5 \\
\hline 6 & Teachers included laboratory in their teaching methods & 2 & 3 & 4 & 2 & 11 & 27.5 \\
\hline 7 & Teachers using field observation & 1 & 1 & 2 & 1 & 5 & 12.5 \\
\hline 8 & Teachers giving practical assignments & 2 & 3 & 6 & 5 & 16 & 40 \\
\hline 9 & Teachers encouraging experimenting/innovating & - & 3 & - & 2 & 5 & 12.5 \\
\hline 10 & Teachers using project work as assessment methods & 1 & - & - & - & 1 & 2.5 \\
\hline
\end{tabular}

The data implies that, all of the respondents believe that skill developing practice, which follows application of what is learned, is important at preparatory school level. This shows that the teachers have the knowledge about the necessity of practical-based education to increase knowledge and skill of the students.

Using pictures and laboratories promote practical teachinglearning activities. But, only an average percentage of about $5 \%$ teachers were using laboratories. However, most teachers $(72.5 \%)$ used pictorial teaching aids to support the students' achievement according to this finding. Similarly, a small number of teachers facilitate field observation for their students to effect their learning. Again only few teachers used to give experimental assignments to their students that may limit independent practice of the students.

\subsection{Students' Attitude Towards Practical Learning}

The result of this study showed that about $86 \%$ of the students under study were aware of the importance of practical-based learning (Figure 3). But, they were not benefited from practical activities that may help them to simplify learning and develop skills related to their education. They attributed the failure to limited professionals, materials and interest of teachers.

Even though the students understood the importance of practical learning, close evaluation of the data indicates that the students have low interest in laboratory work or experimenting (25\% respondents) and field visit or work visit (7\% respondents) activities as a method of learning. This may result from lack of awareness and encouragement to learn practically from their real environment.

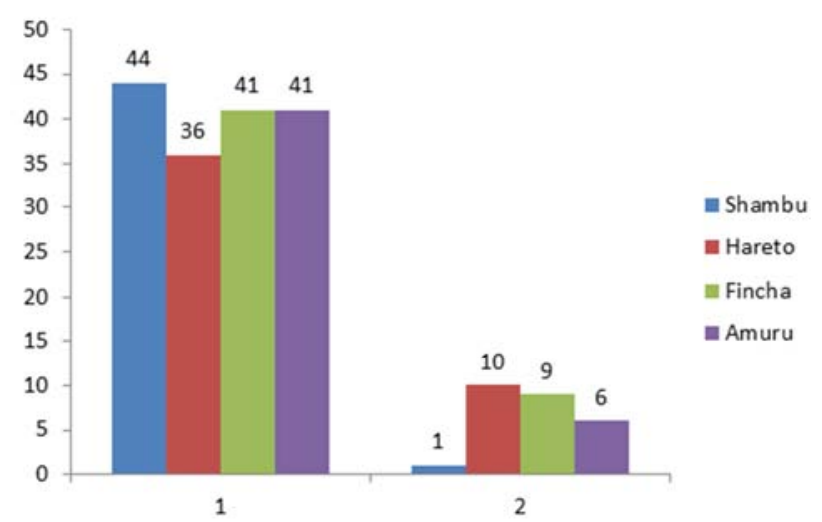

Figure 3. Awareness of students about importance of practical learning $(1=$ who think that practical learning is important, $2=$ who think that practical learning is not important).

According to the data (Table 7 ), about $87 \%$ of the students were interested in learning by doing and about $69 \%$ were interested in using laboratories to learn. Only about $22 \%$ of the students were trying to experiment what they learned theoretically. The students responded that they tried to memorize what they learned by reading repeatedly instead of experimenting or inferring practically.

The present finding showed that only $25 \%$ of the students have an idea that they learn to obtain sufficient capacity to do things correctly. Conversely, about $72 \%$ students responded that they know where to apply what they learned. This controversy may imply that the students' thought of their career fate is not clear. They considered Practical learning as fulfillment to pass exams and join higher education or certified to get job. 
Table 7. Assessment of students' attitude and interest in practical-based learning.

\begin{tabular}{|c|c|c|c|c|c|c|c|}
\hline \multirow{2}{*}{ No. } & \multirow{2}{*}{ Subject } & \multicolumn{4}{|l|}{ School } & \multirow{2}{*}{ Total } & \multirow{2}{*}{ Percentage } \\
\hline & & Shambu & Hareto & Fincha & Amuru & & \\
\hline 1 & Students interested in learning by doing & 45 & 41 & 45 & 43 & 174 & 87 \\
\hline 2 & Students having habit of repeating what they learned & 41 & 37 & 35 & 37 & 150 & 75 \\
\hline 3 & Students trying to experiment what they learned & 13 & 12 & 9 & 10 & 44 & 22 \\
\hline 4 & Students interested in using laboratories & 38 & 32 & 41 & 28 & 139 & 69.5 \\
\hline 5 & Students ever given experimental assignment & 27 & 27 & 29 & 34 & 117 & 58.5 \\
\hline 6 & Students interested in Laboratory work/experimenting & 17 & 11 & 9 & 13 & 50 & 25 \\
\hline 7 & Students interested in Field visit/work visit & 9 & 4 & 0 & 2 & 15 & 7.5 \\
\hline 8 & Students having information where to apply what they learned & 35 & 35 & 40 & 35 & 145 & 72.5 \\
\hline 9 & Students learning to obtain sufficient capacity to do things correctly & 15 & 12 & 13 & 11 & 51 & 25.5 \\
\hline
\end{tabular}

\subsection{Teaching Methods}

The assessment revealed that more than half of the teachers were not happy with their profession. Some interviewed teachers responded that they do the job only not to miss the insufficient salary income. These may be the case that most teachers were not series to design varies teaching methods which may improve students' achievement. Teaching methods most frequently used in the schools considered for this study were traditional methods like lecturing and participative lecturing. Therefore, the existing environment during this study did not encourage active teaching-learning activity.

Majority of the teachers used asking questions to help their students internalize what they learned. But, only about 38\% of them encourage their students to do practical assignments for acquiring a long lasting knowledge and skill. And less than $15 \%$ of the teachers were striving to shape the experimenting (innovating) behaviors of their students which may initiate their independent knowledge and skill acquisition.

The response of the teachers to specific teaching methods is presented in Table 8 . The teaching methods assessed are those that were assumed to be commonly used.

Table 8. Response of teachers to selected teaching methods.

\begin{tabular}{|c|c|c|c|c|c|c|c|c|}
\hline No. & Subject & School & $\mathbf{A}$ & B & $\mathrm{C}$ & D & $\mathbf{E}$ & Total \\
\hline \multirow{4}{*}{1} & \multirow{4}{*}{ Lecture } & Shambu & 2 & 2 & 6 & & & 10 \\
\hline & & Hareto & 1 & 5 & 3 & 1 & & 10 \\
\hline & & Fincha & 5 & 3 & 1 & 1 & & 10 \\
\hline & & Amuru & 3 & 3 & 4 & & & 10 \\
\hline \multirow{4}{*}{2} & \multirow{4}{*}{$\begin{array}{l}\text { Participative } \\
\text { Lecture }\end{array}$} & Shambu & 2 & 3 & 5 & & & 10 \\
\hline & & Hareto & 2 & 6 & 1 & 1 & & 10 \\
\hline & & Fincha & 3 & 4 & 2 & 1 & & 10 \\
\hline & & Amuru & 3 & 3 & 3 & 1 & & 9 \\
\hline \multirow{4}{*}{3} & \multirow{4}{*}{$\begin{array}{l}\text { Peer - } \\
\text { presentation }\end{array}$} & Shambu & & 1 & 4 & 5 & & 10 \\
\hline & & Hareto & 1 & 2 & 7 & & & 10 \\
\hline & & Fincha & & 1 & 4 & 5 & & 10 \\
\hline & & Amuru & 1 & 2 & 5 & & 1 & 9 \\
\hline \multirow{4}{*}{4} & \multirow{4}{*}{$\begin{array}{l}\text { Group } \\
\text { discussion }\end{array}$} & Shambu & 1 & 3 & 6 & & & 10 \\
\hline & & Hareto & 1 & 1 & 8 & & & 10 \\
\hline & & Fincha & 1 & & 6 & 2 & 1 & 10 \\
\hline & & Amuru & & 1 & 8 & & & 9 \\
\hline \multirow{4}{*}{5} & \multirow{4}{*}{ Group project } & Shambu & & 1 & 6 & 3 & & 10 \\
\hline & & Hareto & & 1 & 5 & 4 & & 10 \\
\hline & & Fincha & & & 3 & 6 & 1 & 10 \\
\hline & & Amuru & & 1 & 4 & 1 & 3 & 9 \\
\hline
\end{tabular}

\begin{tabular}{lllllllll}
\hline No. Subject & School & A & B & C & D & E & Total \\
\hline \multirow{4}{*}{6} & \multirow{2}{*}{6} & Shambu & & & 6 & 4 & & 10 \\
& Practical & Hareto & & 1 & 6 & 2 & 1 & 10 \\
& assignment & Fincha & 1 & 2 & 2 & 3 & 2 & 10 \\
& & Amuru & & 4 & 4 & & 1 & 9 \\
\multirow{4}{*}{7} & Shambu & 1 & 2 & 5 & 1 & 1 & 10 \\
& \multirow{3}{*}{ Reading } & Hareto & & 3 & 6 & & 1 & 10 \\
& assignment & Fincha & 3 & 1 & 2 & 3 & 1 & 10 \\
& Amuru & & & 5 & 2 & 2 & 9 \\
\hline
\end{tabular}

$\mathrm{A}=$ always, $\mathrm{B}=$ frequently, $\mathrm{C}=$ sometimes, $\mathrm{D}=$ rarely, $\mathrm{E}=$ never

The comparison of the frequency of the specified teaching methods used are sorted and presented clearly shown in Figure 4. According to this finding, the teaching methods always and frequently used are lecture and participative lecture. The others such as Peer - presentation, Group discussion and Group project are either sometimes or rarely used. Even, Practical assignment and Reading assignment were never implemented by some teachers.

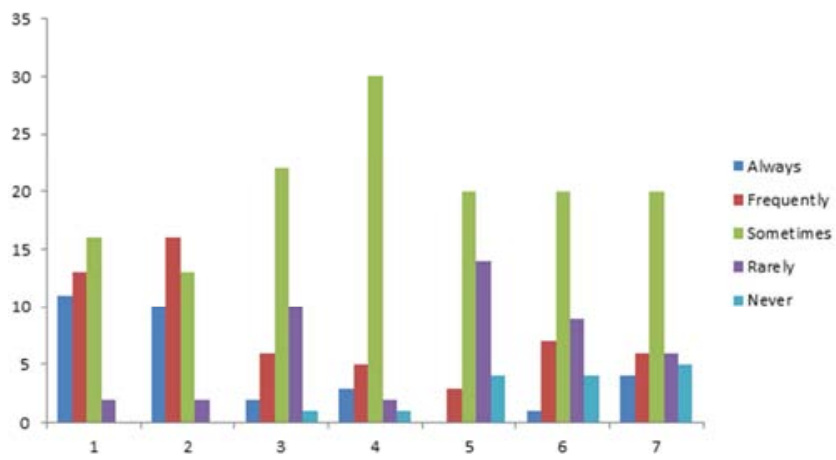

Figure 4. Comparison of selected teaching methods $(1=$ Lecture, $2=$ Participative Lecture, $3=$ Peer - presentation, $4=$ Group discussion, $5=$ Group project, $6=$ Practical assignment, $7=$ Reading assignment $)$.

\subsection{Assessment Methods}

Appropriate assessment methods are very important in education to monitor and measure the achievement of desired knowledge and skill. Assessment methods frequently used were based on mid and final examinations whose items were mainly of "choice". Teachers argued that the students also prefer "choice" and "true/false" items than essay and work out questions. On the other hand, students responded that most teachers prefer "choice" and "workout" assessment items for science and mathematics subjects. In both cases, the data showed that the assessment methods focus on pen and 
paper value following the theory based teaching-learning activities. Therefore, the assessment methods that were used during this study were not supporting practical active teaching - learning practices.

\section{Discussion}

Glance information collected from the target schools such as class size, student-teacher ratio, and laboratory availability/facilities were investigated to see their effect on practical-based education. Class size defined as the actual number of students taught by a teacher at a particular time during a school year [8], [18]. According to this study, relatively large class size was observed in Hareto preparatory school (75) and secondly Fincha school (62). The figure was smaller and equal for the other two schools, which were about 53 students per class.

Studies showed that low student-teacher ratio and small class size has stronger positive effects in secondary schools. The smaller class-size and the lower student-teacher ratio had impact on student achievement. The findings revealed that academic achievement was increased significantly in the smaller class size in the regular classes [15]. But some studies showed that class size does not significantly affect student academic achievement [18]. The relationship between class-size and learning achievement could not be conclusive because different studies result in different outcomes based on different subject areas.

Student-teacher ratio is defined as the number of student in a school compared to the number of teaching professionals [18]. When the figure of the schools under study compared with the standard of 40 students per teacher as set by UNESCO (United Nations Educational, Scientific \& Cultural Organization) and other international organizations, it is not very high. In situations where the number of students per teacher is higher, student-teacher interaction becomes poor. As a result, the management of classrooms and students' learning becomes difficult [15]. But, in this finding the student-teacher ratio was below the set standard. Therefore, it could not be considered as a reason for poor student-teacher interaction and for difficulties to control the class activities.

If the schools under study are considered separately, there is large difference. The student-teacher ratio wasacceptable according to the standard set by UNESCO and others mentioned here only in two schools (Shambu, 25 and Amuru, 29). However, in the case of Hareto school (43) it is greater.

Instead of class size and student-teacher ratio, studentteacher relationships and teacher quality are the most influencing factors [18]. The essence of a strong teacherstudent relationship revolves around how it affects the teaching and the learning going on in a classroom [3]. The present study showed good student-teacher relationship according to the students' response. But the teachers argued that their students do not want to make effective educational relationship with them. But studies showed that students' learning increases within a positive classroom climate and cooperative teacher behavior. This suggests that the distance in the relationship between the students and the teacher should be small [24].

The most common way of practically supporting science learning is using laboratories. Studies argued that laboratory method has much more great effects than the traditional method and a critical variable in determining the quality of output from secondary schools [6], [23]. Laboratory investigation holds significant promise for being able to support conceptual and epistemological learning when facilitating conditions are put in place for students [2]. But in the target study area the laboratory facilities are none in some schools and very limited in the rest. Though school laboratory activities have special potential as media for learning that can promote important science learning outcomes for students [13], [14]; attention was not given as this study revealed.

According to this finding, there were almost no functional laboratories and limited trial to promote practical-based learning even using the available facilities (Figure $1 \&$ Table 6). In two schools (Fincha and Amuru), the laboratories were not functioning at all. Not only shortage of facilities, but also there were no trend of practical learning exercised.

Practical work is an essential component of science teaching and learning, both for the aim of developing students' scientific knowledge and that of developing students' knowledge about science [20]. However, this study indicated that the teaching - learning method was not yet supported by practical activities.

Of course, practical learning can be supported by other methods such as demonstrations, field observations, drawings, project works, etc in addition to laboratory activities. But studies showed that laboratory experimenting is more efficient compared to demonstrations [19]. The current finding showed that the teaching-learning did not support practical learning. But practical learning can help young people to develop good experience, not only in the sector they hope to work within but also of the work environment more generally (Kate, 2008).

The study also proved that the teachers working in the target schools have awareness about the importance of practical-based learning practices at preparatory school level (Table 6). But, in practice the teachers didn't make practical activities the part of their teaching methods (Figure 4) as well as assessment methods. Karamustafaoglu (2009) also reported that although teachers were aware of studentcentered instruction, they were still using traditional techniques widely [16]. This shows that the implementation of practical-based learning needs teachers' commitment. In the schools under study, the teachers complained the load and time constraints. Generally, operating laboratories even using the available materials depend on the good will of the subject teacher to shoulder the load of organizing and preparing the laboratory materials in addition to the class loads.

Students' attitude and perception is also important factor for the success of practical learning. Studies emphasized that student motivation and interest are crucial factors of the educational process [24]. Students under the present study 
didn't have clear perception about the importance of practical learning because they were not using it (Table 7).

Generally, attention was not given to practical science learning by the educational officials, school managers, supervisors, teachers, and other stakeholders. But in science, inquiry-based and problem-based practical learning with attention to active learning under proper guidance, will allow students to construct deeper and longer lasting knowledge, as well as gain a deeper understanding of the scientific process [1]. This implies that it introduce students to conceptual and procedural knowledge and skills in science.

\section{Conclusion and Recommendation}

\subsection{Conclusion}

Practical activities help the students to develop long lasting knowledge and skills useful in understanding the science and in their future carrier. But the study carried out in the schools (Shambu, Fincha, Amuru and Hareto), exposed that little attention was given to practical-based teaching-learning process.

According to the assessment made, most of the students in the schools under study were interested in practical-based education. But, the door was not open for them to undertake practical learning in their real context. However, they have no clear perception about the use of practical learning.

Teachers have positive attitude towards practical learning at principle level; but they didn't implement in the real teaching-learning environment. This indicates that the teachers working in the target schools have awareness about the importance of practical-based learning. But, in practice the teachers didn't make practical activities the part of their teaching and assessment methods.

The teachers and students attributed the failure to limited professionals, materials, interest of teachers and attention given to practical-based learning. Also teachers complained that they didn't get sufficient incentives and professional support.

Generally, practical duties related to learning were not practiced in the preparatory schools considered in this study. The school management, educational offices at all levels and the teachers were not focused on practical-based education system.

\subsection{Recommendations}

According to Ethiopian educational policy, the major objective of preparatory schools is to prepare the students for higher education. After higher education, the educated personnel will join the job world with questionable knowledge and skill. Based on this survey study, the researcher provided the following recommendations for the concerned bodies.

a) The school teachers should be committed to promote practical-based learning for the better human resource product that will contribute to the development of the individuals and the country at large. b) The school officials should give weight to practicalbased learning since it is the way to develop long lasting knowledge and skills. And include practical activities in the school programs.

c) The educational offices at all levels and educational sectors need to pay attention to the practical qualification of the learners and incorporate practical learning in a regular teaching-learning activity.

d) The practical work becomes efficient if laboratory technicians and attendants will be assigned (employed). Assignment of professionals committed to laboratories will reduce teacher's load.

e) Training the teachers may also help to improve their practical skill efficiency so that they may support their students.

f) Further studies should be conducted to investigate how to deep-root practical-based learning in science courses at all levels of education.

\section{Acknowledgement}

This research was funded 11,688.00 Ethiopian Birr by Wollega University in 2008 E.C under the supervision of Shambu Campus.

\section{References}

[1] Almroth, C. (2015). The importance of laboratory exercises in biology teaching; case study in an ecotoxicology course, Institution for Biological and Environmental Sciences, University of Gothenburg, Göteborg, Sweden.

[2] Bell, P. (2004). The school science laboratory: Considerations of learning, technology, and scientific practice, Paper prepared for the meeting: High School Science Laboratories: Role and Vision.

[3] Brady, P. (2014). A case study of student and teacher relationships and the effect on student learning. Open Access Dissertations. Paper 266. http://digitalcommons.uri.edu/oa_diss/266.

[4] Colby, J., Witt, M. and Associates, (2000). Defining Quality in Education, Education Section, Programme Division, UNICEF New York, Document No. $\mathrm{UNICEF} / \mathrm{PD} / \mathrm{ED} / 00 / 02$.

[5] Confrey, J. (1994). A Theory of Intellectual Development for the Learning of Mathematics. FLM Publishing Association: 14,3 .

[6] Demircioğlu, G. \&Yadigaroğlu, M. (2011). The Effect of Laboratory Method on High School Students' Understanding of the Reaction Rate, Western Anatolia Journal of Educational Sciences, 509-516.

[7] Education Funding Agency (EFA) Global Monitoring Report 2005. (2004). Education for All: The Quality Imperative, United Nations Educational, Scientific and Cultural Organization.

[8] Ehrenberg, G., Brewer, J., Gamoran, A., Willms, D. (2001). Class Size and Student Achievement. American Psychological Society, 2, 1, 1-30. 
[9] Fatade, O., Mogari, D., Arigbabu, A. (2013). Effect of problem-based learning on senior secondary school students' achievements in further mathematics, Acta Didactica Napocensia, ISSN 2065-1430, 6, 3, 27-44.

[10] Goodman, J., Sands, M., Coley, J. (2015). America's Skills Challenge: Millennials and the Future, Educational Testing Service Center for Research on Human Capital and Education.

[11] Guy, C., Bill, L., Rob, W. (2010). How the learning sciences could transform practical and vocational education, University of Winchester and Edge Foundation.

[12] Hmelo-Silver, E. (2004). Problem-Based Learning: What and How Do Students Learn? Educational Psychology Review, 16, 3, 235-266.

[13] Hofstein, A. \&Lunetta, N. (2003). The Laboratory in Science Education: Foundations for the Twenty-First Century, Wiley Periodicals, Inc., 28-54.

[14] Hofstein, A. (2004). The Laboratory In Chemistry Education: Thirty Years Of Experience With Developments, Implementation, And Research, Chemistry Education: Research And Practice, 5, 3, 247-264.

[15] Kaloki, J. (2012) Pupil-Teacher Ratio and Its Impact on Academic Performance in Public Primary Schools in Central Division, Machakos County.

[16] Karamustafaoglu, O. (2009). Active learning strategies in physics teaching, Energy Education Science and Technology Part B: Social and Educational Studies, 1(1): 27-50.

[17] Kilpatrick, J. (1987). What constructivism might be in mathematics education. In Bergeron J. C., Herscovics, N., Kieran, C. (Eds.). Proc. 11th Int. Conf. Psychol. Math. Educ. (PME11) I: 3-27.
[18] Kornfeld, M. (2010). The effects of class size on student academic achievement in a rural state, Dissertation, The University of Vermont.

[19] McKee, E., Williamson, M., Ruebush, E. (2007). Effects of a Demonstration Laboratory on Student Learning. J SciEducTechnol, Springer Science+Business Media.

[20] Millar, R. (2004).The role of practical work in the teaching and learning of science,University of York, Department of Educational Studies.

[21] Millar, R. and Abrahams, I. (2009) Practical work: making it more effective, Getting Practical, SSR, 91 (334).

[22] Hazzan, O., Lapidot, T., Ragonis, N. (2014) Guide to Teaching Computer Science: An Activity-Based Approach $\left(2^{\text {nd }}\right.$ Ed.). Springer London Heidelberg New York.

[23] Olufunke, T. (2012). Effect of Availability and Utilization of Physics Laboratory Equipment on Students' Academic Achievement in Senior Secondary School Physics. World Journal of Education, 2, 5.

[24] Petegem, V. (2008). Relationship between student, teacher, classroom characteristics and students' school wellbeing. Universiteit Gent, Faculteit Psychologie En Pedagogische Wetenschappen.

[25] Tate, A., Amedie, Y., Abiche, T. (2011). Mid-Term Evaluation of the USAID Community-School Partnership Program for Education and Health, Report produced by the USAID (United States Agency for International Development).

[26] Topping, K. J. (1998). Peer Assessment between Students in Colleges and Universities, American Educational Research Association, Review of Educational Research, 68, 3, 249-276. 